\title{
Konsep Kohesi Sosial Anggota Yayasan Redline Kediri dalam Menanggulangi Virus HIV
}

\author{
Fidia Astuti ${ }^{1}$, Jainudin ${ }^{2}$ \\ 1Fakultas Ushuluddin dan Dakwah, IAIN Kediri \\ ${ }^{2}$ Fakultas Psikologi dan Kesehatan UIN Sunan Ampel Surabaya
}

DOI: http://doi.org/10.29080/ipp.v11i2.433

\begin{abstract}
Social cohesion is the attachment between members and the desire to remain in the group. This study aims to determine the concept of social cohesion that exists in members of the Kediri Redline Foundation. The foundation is a non-governmental organization engaged in the social and health sector, with the main program to assist people who are stigmatized and discriminated against because of HIV. This study used a qualitative approach and to obtain data, observation, interviews and documentation were used. The subjects of this study involved three members of the Redline foundation. The results showed that in the concept of social cohesion the members have a motive of helping others, providing solutions to each other, maintaining commitment in carrying out routine programs, and maintaining cohesiveness and professionalism.
\end{abstract}

Key word : Concept of Social Cohesion, Redline Foundation, HIV/AIDS

Intisari : Kohesi sosial merupakan keterikatan antar anggota dan keinginan untuk tetap bertahan dalam kelompok. Penelitian ini bertujuan untuk mengetahui konsep kohesi sosial yang ada pada anggota yayasan Redline Kediri. Yayasan tersebut merupakan lembaga swadaya masyarakat yang bergerak di bidang sosial dan kesehatan, dengan program utama mendampingi orang-orang yang mendapatkan stigma dan diskriminasi karena HIV. Penelitian ini menggunakan pendekatan kualitatif dan untuk mendapatkan data maka digunakan observasi, wawancara dan dokumentasi. Subyek penelitian ini melibatkan tiga orang anggota yayasan Redline. Hasil penelitian menunjukkan bahwa dalam konsep kohesi sosial yang dimiliki para anggota adalah motif menolong sesama, saling memberikan solusi, menjaga komitmen dalam menjalankan program rutin yang dibuat, serta menjaga kekompakan dan profesionalisme.

Kata kunci : Konsep Kohesi Sosial, Redline, HIV/AIDS

\section{Pendahuluan}

Kohesi sosial adalah kapabilitas anggota kelompok untuk berperan aktif dan tetap kompak berada di dalam kelompok (Arthur \& Emily, 2010). Hubungan individu dengan anggota lainnya dalam kelompok dapat menunjukkan tingkat kohesi sosial. Kohesi sosial juga dianggap sebagai kemampuan untuk saling terikat antar anggota dan bertahan dalam

Corresponding Author: Fidia Astuti (e-mail: fidia@iainkediri.ac.id) Program Studi Psikologi Islam Fakultas Ushuluddin dan Dakwah IAIN Kediri, Jl. Sunan Ampel No. 07 Kota Kediri, Jawa Timur, Indonesia 64127 
kelompok (Johnson \& Johnson,1994). Pengalaman bersama yang didapatkan oleh para anggota kelompok dalam pergaulan membuat mereka memiliki ikatan untuk terus bergabung dalam kelompok yang dimiliki. Menurut Collins \& Raven (dalam Yusza, Suchiwaty dkk. 2018) Kohesi sosial menjadi kekuatan yang mendorong para anggota agar tetap berada dalam kelompok sehingga kecil kemungkinan mereka akan keluar dari kelompok. Kohesi sosial juga dianggap sebagai kemampuan untuk saling terikat antar anggota dan bertahan dalam kelompok (Johnson \& Johnson,1994).

Menurut Faturochman (2006) suatu kelompok dikatakan kohesif jika setiap anggota memiliki komitmen tinggi dengan kelompok. Selain itu kelompok memiliki interaksi yang sehat artinya kelompok berdasarkan kekompakan bukan persaingan. Kelompok itu juga memiliki tujuan-tujuan yang saling terkait dalam kelompok dan sesuai perkembangan tujuan yang meningkat. Kelompok yang kogesif juga memiliki ketertarikan dalam kelompok yang menciptakan hubungan harmonis. Menurut Ahmadi (2009) kohesi adalah suatu perasaan orang yang bersama - sama dalam kelompok. Pengembangan kohesi sosial dapat membantu mengembangkan kepercayaan, asosiasi antar kelompok, dan jaringan komunikasi dalam kelompok. Council of Europe's Strategy menegaskan bahwa kohesi sosial adalah komitmen sosial yang bertujuan untuk mengurangi perselisihan dan mencegah pengelompokan dalam organisasi dan masyarakat.

Kohesi sosial diartikan dengan sangat beragam karena tergantung pada waktu, budaya dan hubungan sosial yang ada dalam masyarakat. Kohesi sosial kontemporer dilihat sebagai kemampuan suatu masyarakat dalam menciptakan lingkungan yang aman bagi para anggota sehingga terdapat pemenuhan kebutuhan hidup mereka. Council of Europe's Strategy menegaskan kohesi sosial adalah komitmen sosial yang bertujuan untuk mengurangi perselisihan dan mencegah pengelompokan dalam organisasi dan masyarakat. Adapun penelitian yang dilakukan oleh Faisal dan Nain (2018) menyatakan bahwa terciptanya kohesi sosial bersamaan dengan munculnya rasa suka diantara anggota kelompok dalam masyarakat, dan adanya interaksi yang terjadi yang lebih didominasi oleh kerjasama dan memiliki tujuan yang saling terkait satu dengan yang laiannya. Selain itu adapun penelitian yang dilakukan oleh Prananta (2019) menyatakan bahwa pada proses festival Congot di desa Kedungbendo menunjukan adanya sebuah kohesi sosial yang terlihat disetiap rangkaian acara yang dilakukan secara bersama-sama oleh unsur sosial (masyarakat plural) yang digerakkan oleh budaya sehingga terciptanya solidaritas mekanik keagamaan dan organic keagamaan (bersadarkan pada masyarakat yang plural) menjadi satu kesatuan dan dari festival tersebut inilah peran masyarakat sangat penting. Selanjutnya penelitian yang dilakukan oleh Bunyamin, dkk (2019) faktor pendorong terciptanya kohesi sosial di Kampung Ambon, didasarkan beberapa faktor antara lain: Ukhuwah Islamiyah, Tokoh Masyarakat, Hubungan Kekeluargaan, Kegiatan Sosial yang bersama-sama. Serta strategi dakwah seperti santunan anak yatim dan dhuafah.

Seperti yang disampaikan oleh ketiga penelitian di atas bahwa subjek dari kohesi adalah masyarakat. Masyarakat adalah sebuah fakta yang bersifat objektif dari individu individu yang merupakan anggotanya. Masyarakat itu diikat secara kolektif dalam sebuah kelompok. Yayasan Redline adalah salah satu organisasi independent di Kediri yang fokus pada pendampingan orang yang hidup dengan HIV/AIDS, LGBT, disabilitas, perempuan dan anak yang berhadapan dengan hukum. Pada awalnya pergerakan Redline belum banyak dikenal masyarakat karena pihak Redline sendiri tidak ingin mempublikasikan kegiatannya. Namun Redline mulai tidak asing pada masyarakat karena sering membela orang - orang yang sedang berada pada "garis merah" yaitu mereka yang memperoleh stigma dan diskriminasi di masyarakat (https://redlineindonesia.org). Para anggota yayasan Redline harus memiliki jiwa sosial tinggi serta mampu menanamkan konsep kohesi sosial untuk mencari solusi yang terjadi di masyarakat dan pemenuhan hak asasi manusia (HAM) tanpa adanya diskriminasi. Mereka juga harus memegang konsep untuk menyetarakan harkat, 
martabat dan menjunjung tinggi komitmen dalam berpartisipasi di kelompoknya dan membantu individu bebas serta mampu mengembangkan dirinya.

Ada beberapa gangguan kohesi sosial yang dapat terjadi dalam kelompok masyarakat yaitu konflik horizon, konflik atas alasan agama atau kesukuan, pertentangan massal karena kebijakan pemerintah, pertentangan akibat kebijakan yang menimbulkan kecemburuan sosial, dan pemilahan kebijakan yang terlalu disentralisasi (https://sitinurbaya.com/artikelku). Gangguan-gangguan kohesi sosial tersebut juga terjadi pada kelompok independen yang bukan lembaga pemerintahan. Adapun gangguan kohesi sosial yang terjadi pada masyarakat adalah berkurangnya interaksi dilingkungan masyarakat yang memunculkan sifat individualisme sehingga dengan mudah memecah belah hubungan kekerabatan yang telah mengakar dikehidupan masyarakat. Individualisme ini bertentangan dengan prinsip pada masyarakat desa khususnya yang nilai-nilai gotong royongnya dan rasa solidaritasnya tinggi.

Berdasarkan hasil observasi yang dilakukan pada organisasi redline, terlihat ada gejala menurunnya kohesi sosial yang ada disana. Salah satu fenomena yang ditemukan adalah sikap para anggota saat kunjungan ke lapangan. Para anggota yang ada akan melaksanakan sosialisasi HIV kepada sejumlah orang namun sifat individualism mereka muncul karena mereka berangkat sendiri-sendiri ke lokasi. Sebelumnya mereka sudah berkumpul di kantor untuk melakukan kunjungan lapangan namun mereka tidak berangkat bersama. Selain itu ada juga fenomena baru yang terlihat belakangan ini yatu ketika mereka sedang melaksanakan rapat atau diskusi, tidak musyawarah untuk mufakat tetapi lebih pada pemaksaan pendapat anggota yang harus diterima oleh anggota yang lain.

Penelitian tentang kohesi sosial pada anggota redline menjadi penting untuk diteliti karena adanya kekhawatiran akan dampak menurunnya atau bahkan menghilangnya kohesi sosial pada para anggota redline. Adanya pertentangan akibat kebijakan yang menimbulkan kecemburuan sosial pada para anggota merupakan salah satu gangguan kohesi sosial yang paling berdampak pada yayasan redline. Yayasan redline khawatir anggota kelompoknya tidak kompak lagi dan tujuan yayasan yang ingin membantu kaum marjinal tidak dapat tercapai. Penelitian ini akan melihat bagaimana konsep kohesi sosial yang dimiliki oleh para anggota redline terutama pada rasa moral, kerjasama antar individu, serta rasa memiliki satu sama lain pada para anggota redline.

\section{Metode Penelitian}

Penelitian ini bertujuan untuk memahami konsep kohesi sosial yang terjadi pada yayasan Redline dalam menanggulangi virus HIV. Menurut Sugiyono metode kualitatif adalah metode penelitian yang berdasarkan pada filsafat postpositivisme atau enterpretif, digunakan untuk meneliti kondisi objek secara alamiah, di mana peneliti adalah sebagai instrument kunci untuk memahami makna, keunikan, dan mengkonstruksi fenomena (Sugiyono, 2017)

Penelitian ini dilakukan di tempat yayasan Redline Kediri, Jl. Kh. Hasyim Asy'ari Gg. Mawar No.37A, Banjarmlati, Kec. Mojoroto, Kota Kediri, Jawa Timur 64119. Yayasan ini merupakan pembela orang-orang yang berada di garis merah serta memperjuangkan terpenuhinya hak hidup manusia. Fokus penelitian ini adalah konsep kohesi pada anggota yayasan Redline Kediri dalam menanggulangi virus HIV/AIDS. Teknik sampling yang digunakan purposive sampling yakni pengambilan sample dengan cara menetapkan ciri yang sesuai dengan tujuan penelitian. Adapun kriteria subjek yang akan diteliti adalah anggota yang bekerja di yayasan Redline Kediri, staff di kantor dan bagian yang terjun ke lapangan, petugas yang aktif di kantor, serta petugas yang memberi materi pada komunitas yang memiliki resiko tinggi terserang virus HIV.

Wawancara mendalam dilakukan terhadap para anggota yayasan Redline dan observasi terhadap perilaku mereka dalam melakukan kerjasama penanggulangan virus 
HIV. Wawancara dan observasi dalam penelitian ini ditujukan untuk mengetahui bagaimana konsep kohesi sosial anggota yang saat ini terjadi serta bagaimana cara menyukseskan program penanggulangan virus HIV. Sumber data penelitian ada dua yaitu sumber data primer dan sekunder. Sumber data primer diperoleh dari hasil wawancara para anggota yayasan Redline, sedangkan sumber data sekunder diperoleh dari studi literatur dan media masa tetang penanggulangan HIV.

\section{Hasil Penelitian}

Ada beberapa tema jawaban yang didapatkan dari tiga partisipan setelah dilakukan wawancara. Tabel 1 di bawah ini menjabarkan jawaban informan dari pertanyaan yang diberikan. Setiap partisipan mendapatkan pertanyaan yang sama yaitu tentang konsep kohesi sosial, seputar kinerja dan kerjasama. Ada empat hal yang digali dalam penelitian ini dengan meminta informasn menjawab pertanyaan yang telah disiapkan yaitu apa alasan mereka mau bekerja di yayasan Redline, bagaimana proses interaksi yang dilakukan di yayasan Redline, kegiatan apa yang dilakukan secara bersama-sama dalam menanggulangi virus HIV, dan bagaimana kerjasama yang mereka lakukan dengan anggota lain.

Tabel 1

Pertanyaan dan Jawaban Informan

\begin{tabular}{|c|c|c|}
\hline Pertanyaan & Jawaban & $\begin{array}{c}\text { Tema } \\
\end{array}$ \\
\hline $\begin{array}{l}\text { Apa alasan mereka mau } \\
\text { bekerja di yayasan } \\
\text { Redline }\end{array}$ & $\begin{array}{l}\text { 1. } \begin{array}{l}\text { Tergerak hat ingin } \\
\text { membantusesama }\end{array} \\
\text { 2. Merasa terpanggil jiwanya dan ingin } \\
\text { menolong } \\
\text { 3. Bantu dan ingin menolong }\end{array}$ & Motifnya untuk menolong sesama \\
\hline $\begin{array}{l}\text { Bagaimana proses } \\
\text { interaksi yang } \\
\text { dilakukan di yayasan } \\
\text { Redline }\end{array}$ & $\begin{array}{l}\text { 1. Saling memberikan solusi jika ada } \\
\text { masalah dilapangan } \\
\text { 2. Jika ada anggota yang berhalangan } \\
\text { maka anggota lain mengantikan } \\
\text { dengan suka rela. } \\
\text { 3. Jika terjadi kesalahpahaman dalam } \\
\text { berkomunikasi maka koordinator } \\
\text { akan mencari solusi }\end{array}$ & Saling memberikan solusi \\
\hline $\begin{array}{l}\text { Kegiatan apa yang } \\
\text { dilakukan secara } \\
\text { bersama dalam } \\
\text { menanggulangi virus } \\
\text { HIV }\end{array}$ & $\begin{array}{l}\text { 1. Pertemuan rutin dengan stakeholder } \\
\text { 2. Menjangkau populasi kunci dalam } \\
\text { menanggulangi HIV } \\
\text { 3. Memiliki program mobile VCT, } \\
\text { dengan mendatangi hotspot, } \\
\text { komplek lokalisasi, tempat } \\
\text { nongkrong LSL agar lebih mudah } \\
\text { melakukan tes HIV }\end{array}$ & $\begin{array}{l}\text { Komitmen dalam program rutin } \\
\text { yang dibuat }\end{array}$ \\
\hline $\begin{array}{l}\text { Bagaimana kerjasama } \\
\text { yang mereka lakukan } \\
\text { dengan anggota lain. }\end{array}$ & $\begin{array}{l}\text { 1. Mengerjakan dengan professional } \\
\text { sesuai zona } \\
\text { 2. Saling memahami dan } \\
\text { mengutamakan kepentingan } \\
\text { bersama } \\
\text { 3. Rasa kekeluargaan dan saling } \\
\text { mendukung }\end{array}$ & Profesionalisme dan kekompakan \\
\hline
\end{tabular}

Konsep kohesi sosial pada anggota Redline dapat dirangkum dalam empat tema besar yaitu adanya motif menolong sesama, saling memberikan solusi, adanya komitmen dalam program rutin yang dibuat, serta menjaga profesionalisme dan kekompakan dalam melakukan aksinya. 


\section{Pembahasan}

Hasil dari serangkaian wawancara yang dilkakukan peneliti telah menggali konsep kohesi sosial para anggota yayasan Redline dalam menanggulangi virus HIV. Hasil jawaban yang terkumpul selanjutnya dikelompokkan ke dalam empat tema besar yaitu adanya motif menolong sesama, saling memberikan solusi, menjaga komitmen dalam menjalankan program rutin yang dibuat, serta menjaga kekompakan dan profesionalisme.

\section{Motifnya untuk menolong sesama}

Para partisipan menyampaikan bahwa alasan mereka bergabung dalam yayasan redline karena adanya gerakan dalam hatinya untuk membantu orang-orang yang terjangkit virus HIV. Menurut mereka dengan menolong orang-orang tersebut ada rasa kepuasan tersendiri yang dirasakan.

"Saya dan teman-teman redline berkerja atas nama kemanusiaan. Saya sangat merasa iba saat melakukan pendampingan dengan mereka. Beberapa dari mereka menyadari kalau positif tetapi memilih untuk terus melayani pelanggannya dengan alasan mencari nafkah untuk makan sehari- hari. Kadang teman relawan ada yang mengantarkan mereka untuk ikut tes HIV ke rumah sakit".

Motif itulah yang mendasari para anggota bergabung dan bertahan dalam kelompok redline. Memberikan pertolongan pada individu yang terjangkit HIV memberikan para anggota pengalaman tersendiri karena dapat melihat secara langsung apa yang dialami. Seperti pernyataan dari Suryanto,dkk (2012) tentang perilaku menolong adalah sebagai tindakan yang bertujuan untuk menguntungkan orang lain atau kelompok. Niat untuk memberikan manfaat adalah kunci dari pengertian tersebut.

"Saya itu kalau sedang mendampingi mereka sering menjadi tepat curhat meraka kadang kasihan dengan hidupnya, jadi saya tolong sebisanya".

\section{Saling memberikan solusi}

Para anggota melakukan interaksi dengan baik dalam melakukan aksinya. Mereka saling memberikan solusi jika ada masalah di lapangan. Demikian pula saat ada anggota yang tidak bisa datang saat acara sosialisasi dengan alasan sakit atau acara keluarga, maka anggota yang lain akan mengantikan dengan suka rela. Jika terjadi kesalahpahaman dalam berkomunikasi maka koordinator akan memanggil anggota tersebut dan dicarikan solusinya. Konsep kohesi sosial yang disampaikan oleh Faturochman (2006) juga menunjukkan adanya pengaruh interaksi antar individu dalam kelompok. Selain itu ada sejumlah potensi dalam interaksi anggota kelompok yaitu ramah, saling menguatkan, dan saling bekerja sama.

"Saya pernah mbak sakit beberapa hari dan tidak bisa bersama-sama dengan temanteman untuk melakukan sosialisasi. Hari itu jadwal saya yang menjadi penanggung jawab sosialisasi tapi karena keadaan saya sudah lemas dan badan ini panas jadi saya tidak bisa berangkat. Alhamdulillah sekali mbak teman-teman mau backup saya".

Potensi kohesi sosial itu juga dirasakan dalam kelompok redline. Para anggota merasakan mereka seperti memiliki keluarga karena adanya kepeduliaan yang tinggi di antara para anggota. Jika ada yang mengalami masalah ataupun kesulitan maka anggota kelompok saling menguatkan. Penguatan yang diberikan dapat berbentuk materi maupun dukungan. 
"Pulang dari kegiatan sosialisasi teman-teman berkunjung kerumah menjenguk saya. Disitu saya merasa memiliki keluarga baru yang perhatian dengan saya"

\section{Komitmen dalam program rutin yang dibuat}

Tema yang juga ditemukan dalam redline adalah komitmen dalam melaksanakan program rutin yang telah ditetapkan. Sejumlah kegiatan dilakukan bersama dengan tetap ada pertemuan rutin bersama para stakeholder. Dalam melakukan tugasnya para anggota redline menjangkau langsung populasi kunci penderita HIV.

"Mengenai cara menjangkau melalui bagian dari mereka sendiri dengan begitu lebih mempermudah yayasan Redline dalam menjangkau serta menanggulangi virus HIV".

Penanggulangan virus HIV juga dilakukan melalui program mobile VCT yang dibuat. Melalui acara tersebut para anggota redline dapat langsung mendatangi hotspot, komplek lokalisasi, dan tempat nongkrong komunitas LSL. Di sana mereka dapat dengan lebih mudah melakukan tes HIV. Meskipun program ini dilakukan dalam kurun waktu 1 sampai 2 bulanan, namun kegiatan tersebut cukup memberikan dampak yang signifikan.

"Selain itu dengan menjangkau dengan populasi kunci anggota yayasan Redline ini juga memiliki program mobile VCT, acara ini dilakukan dengan mendatangi hotspot, komplek (lokalisasi), tempat nongkrong komunitas LSL supaya mereka lebih mudah dalam melakukan tes HIV, namun program ini dilakukan paling sedikitnya 1 sampai 2 bulanan".

"Meskipun kegiatan sosialisasi kita seperti main- main karena kadang nongkrong di warung kopi, tapi itulah cara pendekatan yang lebih ampuh yang bisa kita lakukan, mereka akan merasa lebih dekat dan kita akan mendapatkan informasi lebih banyak".

Dari jawaban yang terkumpul dapat terlihat bahwa para anggota di yayasan Redline memiliki komitmen untuk melakukan kegiatan bersama dan saling mendukung dalam sejumlah kegiatan. Hal tersebut membuat meraka saling akrab sehingga kohesi sosial di dalam kelompok trersebut semakin terasah. Menurut Nat J. Colletta (dalam Bunyamin, dkk. 2019) menegaskan bahwa kohesi sosial menjadi sarana mempererat masyarakat, membangun keselarasan dan semangat masyarakat. Adanya komitmen untuk mencapai tujuan-tujuan bersama juga merupakan ciri adanya kohesi sosial yang terbentuk dalam sebuah kelompok. Hal tersebut sepedandapat dengan Kondrad Huber (2004) bahwa kohesi sosial merupakan sebuah nilai kearifan local yang dibutuhkan untuk menciptakan perdamaian, keselarasan dan ketentraman dalam kehidupan yang ada dimasyarakat setelah terjadinya konflik.

Adanya kohesi sosial dapat membantu mengembangkan kepercayaan, mengurangi perselisihan dan mencegah pengelompokan dalam organisasi.

"Strategi saya selanjutnya anggota yang ada masalah tadi sudah saling memaafkan dan saya beri tugas yang harus dikerjakan bersama sehingga meraka akan bertukar pikiran atau berusaha mejalankan semaksimal mungkin".

\section{Profesionalisme dan kekompakan}

Menjaga profesionalisme dan kekompakan juga merupakan temuan dari tema kohesi sosial yang dirangkum dari hasil wawancara dengan ketiga partisipan. Semua para anggota semaksimal mungkin mengerjakan semua yang menjadi tugas dan tanggung jawab mereka dalam zona yang telah ditentukan dengan professional. Mereka tetap mengutamakan kepentingan bersama dengan rasa kekeluargaan sehingga kekompakan 
yang dirasakan membuat mereka saling erat dan mendukung satu sama lain. Menurut Nat J. Colletta (dalam Bunyamin, dkk. 2019) Tujuan kohesi sosial adalah terwujudnya kerjasama dengan adanya saling memahami, dan penciptaan kepentingan bersama. Kekompakan itu dapat terlihat dari kerjasama antar anggota yang baik, saling memahami dan mengutamakan kepentingan bersama. Anggota yayasan Redline merasakan kekeluargaan dan dukungan dari para anggota kelompok.

"Saya di Yayasan redline ini sudah hampir 10 tahun mbak sampai diamanahi menjadi koordinator, menurut saya disetiap kelompok/ organisasi itukan ada saja maslahnya iya..., sama ditempat kami juga tetapi kesalah pahaman yang ada tersebut tidak berjalan lama karena akan segera saya selesaikan, biasanya mereka saya dudukan bersama lalu saya ingatkan tujuan dari pada yayasan kita adalah untuk membantu mereka yang sedang menghadapi kesulitan, selanjutnya saya ingatkan tetang lembaga-lembaga lain yang sudah berkerjasama dengan kita yang sudah percaya dengan yayasan kita".

\section{Simpulan dan Saran}

Dari hasil penelitian dan pembahasan di atas maka penelitian ini dapat ditarik kesimpulan bahwa konsep kohesi sosial yang ada pada anggota yayasan Redline, adalah motif menolong sesama, saling memberikan solusi, menjaga komitmen dalam menjalankan program rutin yang dibuat, serta menjaga kekompakan dan profesionalisme. Dukungan teori masih kurang banyak dalam menjelaskan kohesi sosial yang ada dalam kelompok. Selain itu jumlah pertanyaan yang tidak melihat bagaimana dinamika kohesi sosial yang terbentuk juga mnejadi kekurangan penelitian ini. Sejumlah gangguan dalam kohesi sosial pada kelompok redline dapat juga menjadi ide penelitian selanjutnya.

\section{Daftar Pustaka}

Ahmadi, Abu. 2009. Psikologi Sosial. Jakarta: Rineka Cipta

Arthur, S. R. \& Emily S. R. 2010. Kamus Psikologi. Yogyakarta: Pustaka Pelajar.

Bunyamin, dkk. 2019. Kohesi Sosial Umat Islam Antar Jamaah Masjid Ar-Rahman dan alIkhlas di Kampung Ambon. Prosiding Seminar Nasional Penguatan Riset dan Luarannya sebagai Budaya Akademik di Perguruan Tinggi memasuki Era 5.0.

Faisal, Muhammad Faisal dan Nain Umar. 2018. Implikasi Pelaksanaan Program Dana Desa Terhadap Kohesi Sosial Di Desa Tamalate Kabupaten Takalar. Jurnal Ilmu-ilmu Sosial dan Humaniora. 20(3), 229-230

Faturochman. 2006. Pengantar Psikologi Sosial. Yogyakarta: Pustaka

Johnson, Paul D. 1994. Teori Sosiologi: Klasik dan Modern, Jilid I dan II, Terj. Robert M.Z. Lawang. Jakarta: Gramedia

Konrad, et.al.2014. Menuju Pembangunan Damai Membangun Kohesi Sosial dan Rekonsoliasi Sulawesi Tengah dan Maluku Utara. Hasil Penelitian UNDP dan BAPENAS: Jakarta

Pranata, Kikip Gusti. 2019. Festival Congot sebagai pembentukan Kohesi Sosial di Desa Kedungbenda Kecamatan Kemangkoan Kabupaten Purbalingga. Skripsi Program Studi Agama - Agama Fakultas Ushuluddin Adab dan Humaniora IAIN Purwokerto.

Sugiyono. 2019. Metode Penelitian Kuantitatif Kualitatif dan R\&D. Bandung: Alfabeta.

Sugiyono. 2017. Memahami Penelitian Kualitatif. Bandung: Alfabeta.

Suryanto, dkk. 2012. Pengantar Psikologi Sosial. Surabaya: Pustaka penerbitan dan Percetakan Unair (AUP)

Yusza, Suchiwaty dkk. 2018. Efektifitas Bimbingan Kelompok menggunakan permainan simulasi dalam Meningkatkan Kohesi Sosial. Jurnal author and Faculty of education Universitas Negeri Padang. 2(3),1-5

http://lib.unnes.ac.id/17326/1/1301408057.pdf 
https://redlineindonesia.org.

https://www.kompasiana.com/amp/bismasampurna/memahami-konsep-kohesi sosial 5529357cf17e61f14a8b45c1\&ved.

https://sitinurbaya.com/artikelku/126-waspadai-gangguan-kohesi-sosial 